\title{
Sciendo
}

\section{Pancreas divisum: a reemerging risk factor for pancreatic diseases}

\author{
SERGHEI COVANTEV
}

Laboratory of Allergology and Clinical Immunology, "Nicolae Testemitanu"

State University of Medicine and Pharmacy, Chisinau, Republic of Moldova

\begin{abstract}
Pancreas divisum (PD) is the most common developmental anatomic variant of pancreatic duct. The attention towards the PD has grown significantly since there are reports that this condition may cause acute relapsing pancreatitis, chronic pancreatitis and chronic abdominal pain syndrome. Furthermore, over the years, there have been multiple reports of PD associated with different types of tumors. There is evidence that PD can be associated with pancreatic tumors (up to $12.5 \%$ of cases). The golden standard for diagnosing PD is endoscopic retrograde cholangiopancreatography, but since it is an invasive procedure magnetic resonance cholangiopancreatography with secretin is a good alternative. In case the patient is symptomatic, endoscopic or surgical treatment should be performed. This review describes the key points of the pathophysiology, diagnostic modalities, risks of pancreatitis and tumors, as well as treatment options of PD.
\end{abstract}

Keywords: acute relapsing pancreatitis; pancreas divisum; pancreatic tumors.

\section{INTRODUCTION}

The first person who described the pancreas was Claudius Galen (129-199) who provided the first description of the pancreas considering that its function is limited to being a cushion for the stomach. Johann Georg Wirsung (1589-1643) of Augsburg was the first scientist who discovered a ductal system in the pancreas and, until the rest of his life, he tried to find the answer to its function. Giovanni Domenico Santorini (1681-1737) of Venice made the next step in the description of ductal anatomy. He performed several hundred dissections of the pancreas and duodenum and then examined them using a magnifying glass. The results of his study showed that, frequently, the pancreas had a second accessory duct, which is named after him [1].

Pancreas divisum (PD) is the most common developmental anatomic variant of the pancreatic duct [2]. For the first time it was mentioned in the 17 th century, but its description is attributed to Joseph Hyrtl (1810-1894) [3]. Later on in 1903, Eugene L. Opie (1873-1971) precisely described this anatomical variant and was the first to report that in post mortem examinations. PD is encountered in $10 \%$ of cases $[4,5]$. Still even though it is the most widely encountered anatomic variant, $\mathrm{PD}$ is mentioned only in approximately $14 \%$ of the anatomy plus embryology books and in $70 \%$ of the surgery plus pathology books [6].

There is growing evidence that pancreatic ductal anomalies (PD, ansa pancreatica, meandering main pancreatic duct) are linked with pancreatic diseases [7-10]. The attention towards the PD has grown significantly since there are reports that this condition may cause acute relapsing pancreatitis (ARP), chronic pancreatitis (CP) and chronic abdominal pain (CAP) syndrome [11]. The current data indicates that the recurrence rate of acute pancreatitis can be up to $80 \%$ in patients with pancreaticobiliary malformation [12]. There are other malformations such as congenital cystic dilatation of the common bile duct which are also linked to this condition [7]. With all of this in mind, PD reemerges as risk factor in pancreatic diseases.

\section{EMBRYOLOGY AND PATHOPHYSIOLOGY}

In the normal pancreas, the Wirsung's and Santorini ducts have connections (figure 1). PD is a developmental anomaly, which represents the absence of fusion between the dorsal (Santorini) and ventral (Wirsung) pancreatic ducts. In such cases, the dorsal duct drains most of the pancreas and there- 
fore it has the role of the main pancreatic duct [13]. The abnormal fusion causes abnormal drainage of the majority of the pancreatic juice into the minor papilla and the minority (about 10\%) through the major papilla [14, 15]. Furthermore, in patients with pancreas divisum, intraductal pressure can be elevated and this may persist during the fasting state [16]. Among other causes of pancreatitis, a stenosis of the accessory papilla of Santorini can be coexistent in pancreas divisum $[17,18]$. Two common features are of particular importance in this anomaly. The first is ductal stenosis either at its ampullary outlet or at the junction part of the ducts of the pancreas. The second is a localized ductal ectasia, particularly in the uncinate process that is commonly associated with ampullary stenosis [18].

PD models were also tested in animals. In a PD canine model a group of dogs were divided into subgroups. The group I in which the communicating branch that connects the dorsal and ventral pancreatic ducts was partly ligated, the group IIa in which the connecting branch was amputated and completely ligated and the group IIb in which the dorsal duct was amputated and then ligated. The pancreas tissue was evaluated under light microscopy. In group IIb there was fibrosis with destruction of acini with evidence of inflamemation in the dorsal and ventral pancreas. Similar results were seen in Groups I and IIa but only in the ventral pancreas. Furthermore, there was a decrease in zymogen granules, swollen mitochondria and endoplasmic reticulum dilatation in the ventral pancreas of Groups I and IIa and the dorsal and ventral pancreas of Group IIb. Thus, the experimental canine model demonstrated that the pathogenesis of this condition is the functional obstruction of the minor papilla at the peak stage of secretion and PD can be an etiological factor for pancreatitis [19].
PD is usually asymptomatic, but recent data indicates that there may be links between PD, chronic abdominal pain (up to $60 \%$ ) and idiopathic pancreatitis (up to 30\%) [13]. Nevertheless, not all specialists agree that it may be a risk factor for pancreatitis and other authors state that it does not modify the course of the disease in some of the types of pancreatitis $[20,21]$.

\section{INCIDENCE AND CLASSIFICATION}

PD incidence is different and depends on the investigated population and the methods used. It can be diagnosed in $5-11 \%$ by magnetic resonance cholangiopancreatography (MRCP) [22-25], 9-16.8\% secretin MRCP [23, 24, 26], 0.47-2.3\% endoscopic retrograde cholangiopancreatography (ERCP) [27, 28 ], $13.6 \%$ by endoscopic ultrasound (EUS) [29], $4-14 \%$ autopsy $[27,30]$. Besides, the overall endoscopic detection rate for PD seems to be higher in some parts of the world. For example, endoscopic detection rate for PD was $5.8 \%$ in the USA, $6.0 \%$ in Europe and only 1.5\% in Asia [31].

PD can be classified in three main types [18]:

- Type 1 (classic PD) is the complete failure of fusion of the ducts of Santorini and Wirsung $70 \%$. It can be further divided into two subtypes. The first subtype - the main pancreatic duct drains into the duct of Santorini (figure 2). The second (atypical or inverted PD) - the main pancreatic duct drains in the Wirsung's duct (figure 3).

- Type 2 is the absence of the duct of Wirsung 20-25\%

- Type 3 (incomplete PD) is the presence of a small connection between the dorsal duct and the ventral duct 5-6\%.

Table 1

Diagnostic test for PD

\begin{tabular}{|c|c|c|c|}
\hline Test & Sensitivity & Specificity & General comments \\
\hline S-MRCP & $67-84.5 \%$ & $88.1-96.8 \%$ & Misdiagnosis of PD can be in case of: \\
\hline MRCP & $60-72.2$ & $76.2-93.8 \%$ & - presence of pancreatic necrosis \\
\hline MDCT & $57.1-83.3 \%$ & $39.3 \%$ & - changes due to acute or chronic pancreatitis \\
\hline EUS & $86.7-95 \%$ & $97 \%$ & $\begin{array}{l}\text { - use of suboptimal technique } \\
\text { - inexperienced examiners } \\
\text { - presence of a loop in the main duct or other anomalies } \\
\text { - presence of ductal strictures }\end{array}$ \\
\hline
\end{tabular}

MRCP - magnetic resonance cholangiopancreatography, S-MRCP - magnetic resonance cholangiopancreatography with secretin, MDCT - multiple detector computed tomography, EUS - endoscopic ultrasound 


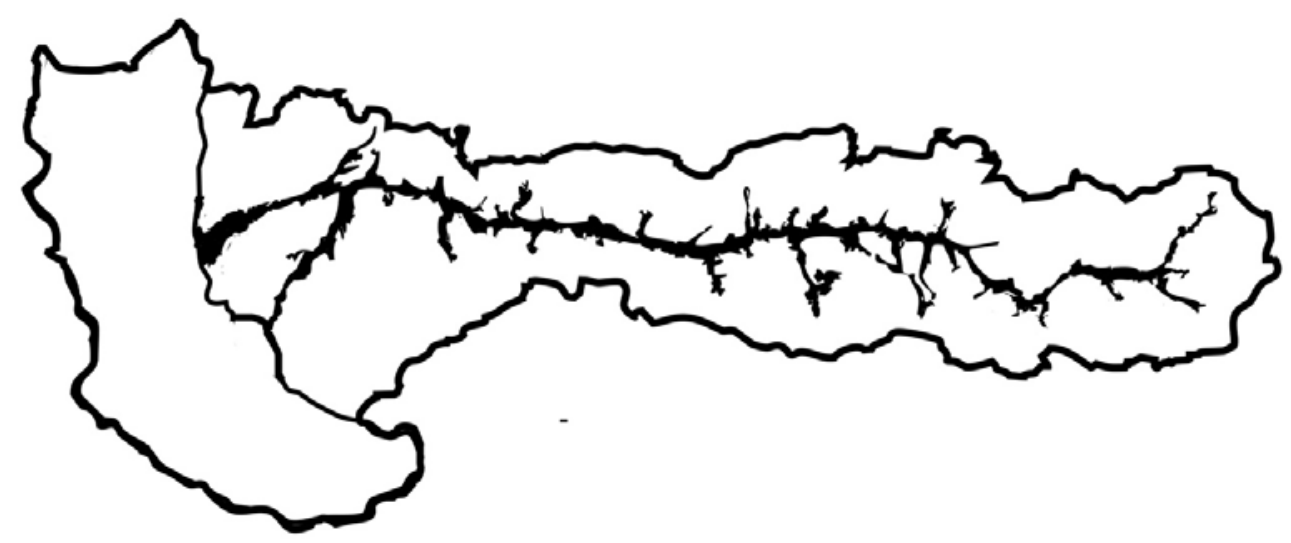

Figure 1. Normal pancreatic duct morphology.

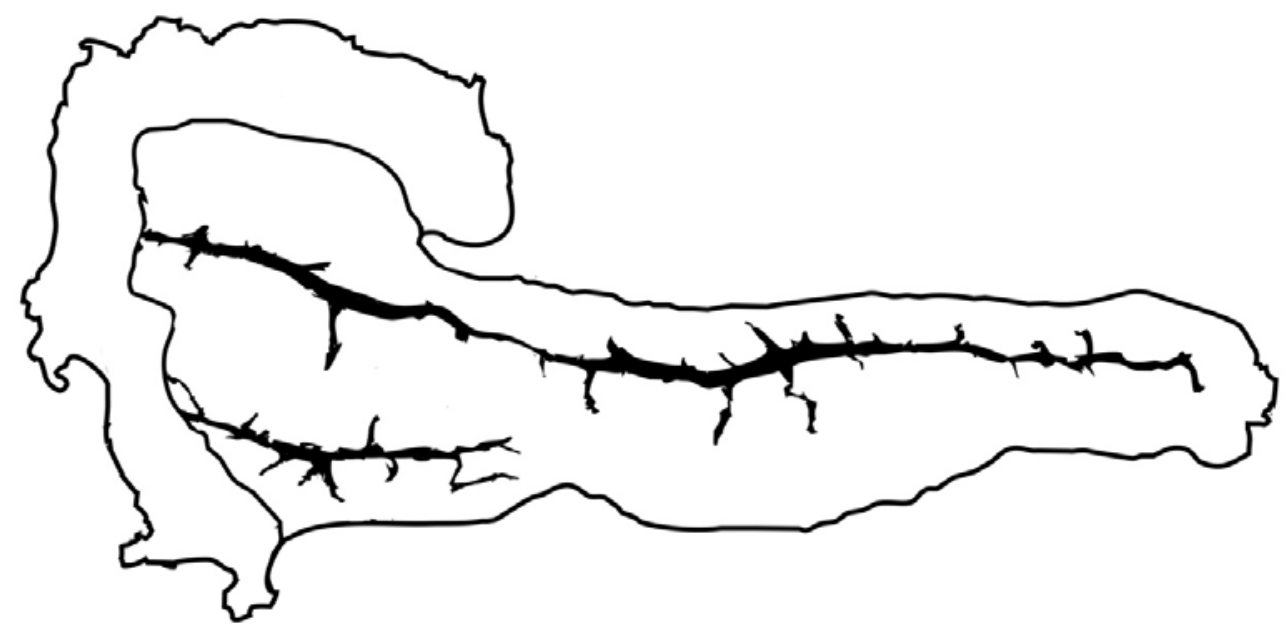

Figure 2. Classical pancreas divisum.

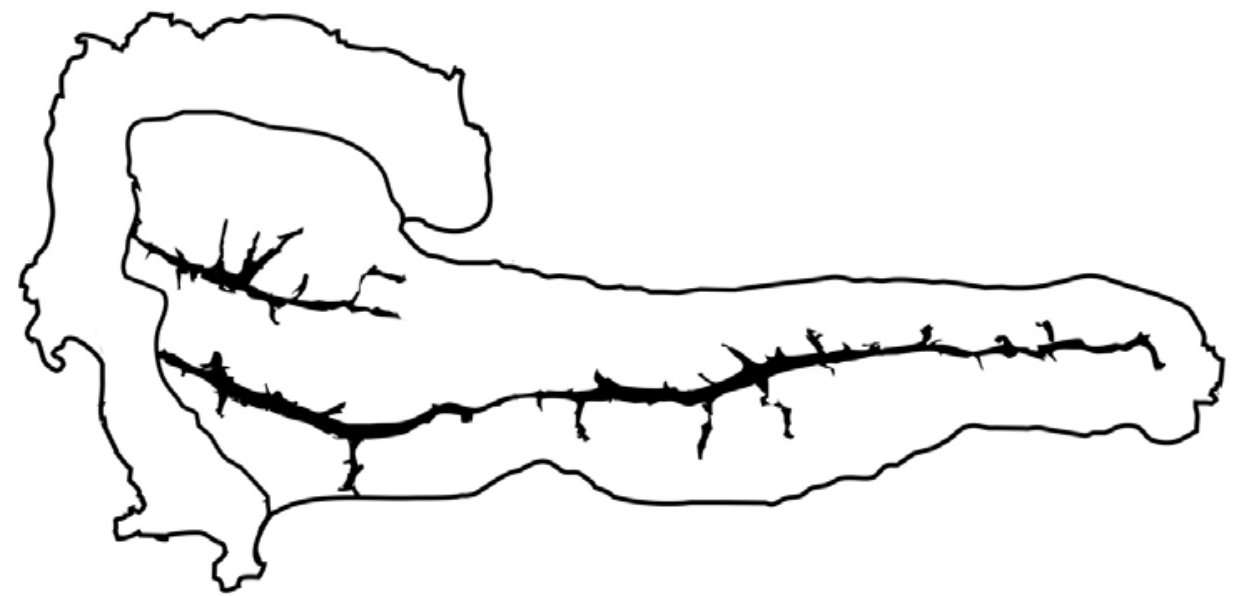

Figure 3. Atypical or inverted pancreas divisum.

DIAGNOSTIC POSSIBILITIES

AND ASSOCIATED RISKS

Several diagnostic modalities have been developed over the years with different sensitivity and specificity to diagnose PD.
ERCP is considered the golden standard for diagnosing PD but is an invasive procedure. It was developed in 1968 and has become a widely used imaging technique in the diagnosis of pancreatobiliary diseases. ERCP provides a radiological image of the morphology and the pathological changes of 
the pancreatic ducts and biliary tree. This image is obtained by the injection of a contrast agent into the main pancreatic duct and common bile [32]. Nowadays, due to the availability of modern noninvasive imaging modalities such as abdominal ultrasound (AUS), computed tomography (CT), MRCP and EUS (Table 1) ERCP has transformed from a diagnostic technique to mostly a therapeutic procedure [26, 29, 33-39].

The most frequent complications of ERCP are pancreatitis $(1-7 \%)$, perforation $(0.1 \%-0.6 \%)$ and bleeding (1-2\%) [40, 41]. Other complications include infections $(1.44 \%)$, cardiovascular and/or analgesia-related complications (1.33\%), and although rare $(0.07-0.08 \%)$ fatalities can also occur $[42,43]$. The rate of complications depends significantly on the experience of medical personnel and whether they are performed in high-volume advanced centers [43]. The rate post-ERCP complications in children are around $4-10 \%[44,45]$. On multivariate analysis, pancreatic duct cannulation is associated with pancreatitis (OR 3.48). Moreover, in the same study age less than 4 years (10.7), male gender (12.8), and precut sphincterotomy (31.3) were associated with hemorrhage (all $p<0.05)$ [45]. Nevertheless others report that there are no significant differences between the underaged and the adult groups in terms of complications and longterm follow-up results [46].

However, it seems that this risk is higher in case of PD. One of the large retrospective studies on ERCP performed in patients with PD from 1997 to 2010 demonstrated that early complications occurred after $7.8 \%$ of procedures. These complications included post-ERCP pancreatitis in $6.8 \%$, hemorrhage in $0.7 \%$, perforation in $0.2 \%$, cholecystitis in $0.1 \%$, and cardiorespiratory complications in $0.1 \%$ of cases. Post-ERCP pancreatitis was uncommon in patients who did not have dorsal duct cannulation and occurred in $1.2 \%$ of procedures. In case of dorsal duct cannulation the rate of post-ERCP pancreatitis increases to $8.2 \%(\mathrm{p}<0.01)$. When cannulation with minor papilla sphincterotomy was performed the rates of post-ERCP pancreatitis increased even higher to $10.6 \%(\mathrm{p}<0.01)$. Multivariate logistic regression analysis demonstrated that significant predictors of post-ERCP pancreatitis included several factors: age $<40$ (OR 1.8; 95\% CI, 1.27-2.59), female sex (OR 1.94; 95\% CI, 1.25 3.01), previous post-ERCP pancreatitis (OR 2.02; 95\% CI, 1.32-3.1), an attempt for dorsal duct cannulation (OR 7.45; 95\% CI, 3.25-17.07), and minor papilla sphincterotomy (OR 1.62; 95\% CI,
1.05-2.48). Interestingly, the presence of severe chronic pancreatitis seemed to be a protective factor (OR 0.46; 95\% CI, 0.22-0.98) [47].

Although ERCP is considered the golden standard of diagnosis, several studies demonstrated that there is a significant correlation between MRCP and ERCP in terms of detecting pancreatic diseases $[48,49]$.

MRCP is a diagnostic technique that produces high-quality images of the pancreatobiliary tree. There are several advantages which include its noninvasiveness; no complication, no radiation and no contrast agent. As a result, it causes less discomfort for the patients, and provides a large amount of information about the surrounding organs [50]. The injection of secretin (S-MRCP) which causes temporary dilation of the pancreatic ducts, principally by increasing pancreatic exocrine secretions, can further improve MRCP detection of the ducts and characterization of pancreatic disorders, allowing to asses the exocrine pancreatic reserve [51]. A recent meta-analysis based on 16 studies has demonstrated that the sensitivity and specificity for MRCP diagnosis of PD was 0.59 (95\% CI 0.45 to 0.71 ) and 0.99 (95\% CI 0.96 to 1.00). Compared to MRCP the sensitivity of S-MRCP was higher ( 0.83 [95\% CI 0.66 to 0.92$]$ ) with the same sensitivity and specificity (0.99 [95\% CI 0.96 to 1.00$])$ [52].

Finally, EUS is another widely used procedure for the visualization of the pancreas, which developed as an alternative for transabdominal ultrasonography, where intervening air does not permit good visualization of the organ [53]. The sensitivity and specificity for EUS was 0.85 (95\% CI 0.67 to 0.94 ) and 0.97 (95\% CI 0.90 to 0.99 ), respectively [52].

\section{PD AND PANCREATITIS}

The idea of PD being a risk factor for pancreatitis has been discussed for many years [54, 55]. Cotton in 1980 noted that in 169 patients with primary biliary tract PD was seen $3.6 \%$. Among 78 patients with unexplained recurrent pancreatitis, the incidence was $25.6 \%$ [56]. In $18.8-20 \%$ of patients who have idiopathic pancreatitis the only finding on ERCP was PD [57, 58]. Moreover, it seems that patients with ARP also have PD more frequently $(p=0.004)$ [59]. Some authors support the theory that isolated dorsal pancreatitis may be the predominant form [60]. The prevalence of CP in patients who have complete or incomplete PD is significantly 
higher compared to controls $(\mathrm{p}<0.001$ and $\mathrm{p}=0.001$, respectively). Moreover acute pancreatitis occurs more frequently only in patients with complete PD $(p=0.01)$ [61]. It seems that PD can be the sole etiology of acute or chronic pancreatitis or require another factor (such as alcohol abuse), for its development [62].

There are no gender preferences, but there are genetic basis for PD [63]. Patients with PD are more likely to have mutations that cause predisposition for pancreatitis $(27 \% v s 14 \%, \mathrm{p}=0.0007)$ [64]

The frequency of PD is higher in patients who have CFTR gene-associated pancreatitis compared to those with idiopathic and alcoholic pancreatitis $(p<0.0001)$. CFTR gene is of particular interest since PD is seen less frequently in SPINK1 and PRSS1 gene-associated pancreatitis $(p<0.02)$ [65]. Nevertheless, gene mutations may be the main factor but more probably are a co-factor in causing pancreatitis in this group of patients [66]. Some of the mutations of the SPINK1 gene cause a more severe clinical course and strong association of early-onset type of patients with idiopathic pancreatitis $[67,68]$.

It seems that the frequency of abnormalities of the main pancreatic duct, side branch dilatation, and pancreatic cysts are significantly different between the PD group and the non-PD group $(\mathrm{p}=$ $0.122 ; p=0.152 ; p=0.741)$. But there was no association between PD and pancreatic exocrine function $(p=0.367)$ [35]. Nevertheless, there are reports of complications such as cystic dilatation of the dorsal pancreatic duct [69], obstruction at the minor papilla [70], obstructing pseudocyst of the duct of Santorini [71]. There are also case reports that indicate that PD may be associated with other anomalies [72].

Finally, there is also data about drug-induced acute pancreatitis in patients with PD although no large studies have been conducted to prove whether $\mathrm{PD}$ is associated with drug-induced pancreatitis [73].

\section{PD AND TUMORS}

Over the years, there have been multiple reports of PD associated with different types of tumors [74-77]. There is evidence that PD can be associated with pancreatic tumors (up to $12.5 \%$ of cases). It is presumed that the pancreatic duct obstruction, which is caused by relative stenosis of the minor duodenal papilla, can lead to oncogenesis [78].
In one of the retrospective single-center studies, a total number of 118 cases of complete PD and 7850 cases of fused pancreas were identified with ERCP examinations. The prevalence of tumors was higher in PD group for pancreatic cancer $(10 \% v s$ $4.8 \%$ ), intraductal papillary mucinous neoplasms $(5.1 \%$ vs $2.6 \%)$ and other pancreatic tumors $(2.5 \%$ vs $1.1 \%)(\mathrm{p}=0.008$; OR, 2.24). The percentages of PD patients with pancreatic cancer who had pain and elevation of serum pancreatic enzymes were significantly higher than among the PD patients without pancreatic cancer. Thus, the conclusion was that patients with $\mathrm{PD}$, especially those who have pancreatic-type pain and elevation of pancreatic enzymes, should be followed up due to their risk of developing pancreatic cancer [79].

On the other hand, the incidence of biliary tract cancer was lower in patients with PD compared with fused pancreas $(0.8 \%$ vs $5.3 \%, \mathrm{p}=0.031)$ [79]. Kamisawa and coworkers report that in concomitant pancreaticobiliary maljunction and incomplete PD the incidence of cancer of the biliary tract may be lower. The explanation was that the pancreatic juice reflux into the bile duct is reduced by the flow of pancreatic juice into the duodenum through the dorsal duct [80]. Another study finds that both pancreatic and biliary tumors are more frequent in patients with PD than in those with a dominant ventral duct $(p=0.0383)$ [81].

Nevertheless, it is worth mentioning that dilatation of the dorsal pancreatic duct is sometimes observed in cases of PD without the presence of tumors. In these cases there is pancreatic duct stenosis and additional examinations are required in order not to overlook a malignant process [82].

\section{MANAGEMENT OF PD}

Although PD can present with clinical symptoms it also can be asymptomatic [13]. Treatment is indicated in case of CAP, ARP or CP. The two main types of treatment for PD are endoscopic and surgical.

Endoscopic interventions include minor papillotomy, endoscopic stenting, and balloon dilation of the minor papilla. A recent meta-analysis demonstrated that the rate of improvement after endoscopic therapy varied significantly across studies, ranging from 31 to $96 \%$. The pooled efficacy rate was $67.5 \%$ (95\% CI $0.610-0.734 ; \mathrm{p}=0.0001)$. On subgroup analysis, patients with ARP had better endoscopic outcomes (pooled efficacy rate $76 \%$, 
95\% CI 0.712-0.803, $\mathrm{p}=0.0001$ ). Dorsal duct stenting and longer follow up were the only parameters predictive of successful therapy. The pooled rate of pancreatitis after endoscopic retrograde cholangiopancreatography was $10.1 \%$ (95\%; CI $0.084-$ 0.124; $p=0.0001$ ) [83].

Endoscopic treatment seems to depend on the underlying condition. A systematic review of case series and case-control studies demonstrated that the efficiency for ARP was $43 \%$ to $100 \%$ (median $76 \%$ ) whereas for CP $21 \%$ to $80 \%$ (median $42 \%$ ) and for CAP 11\%-55\% (median 33\%). Despite endoscopic therapy, patients with PD still have relapse rates of $50 \%(95 \% \mathrm{CI}, 35$ to $68 \%)$ [84]. Nevertheless, after endoscopic stenting the overall pain level and number of hospital admissions decreased significantly. The use of pain medication reported by the patients was decreased in $58 \%$ of patients, $21 \%$ remained the same, and increased in $13 \%$ of cases. There was also improvement in symptoms like nausea $(67 \%)$, vomiting $(63 \%)$, and chronic pain (75\%) [85]. In case of failure, there is a number of surgical procedures that can be performed (accessory duct sphincteroplasty alone or in combination with major sphincteroplasty and septoplasty, pancreaticojejunostomy, duodenum- preserving resection of the pancreatic head, cholecystectomy) [86-89].

Finally, a recent systematic review, which included 56 observational studies (31 endoscopic and 25 surgical studies), demonstrates that surgery was superior to endoscopic treatment. Surgery had a higher success rate $(72 \%$ vs 62.3$)$, lower complication rate $(23.8 \%$ vs $31.3 \%)$ and lower reintervention rate $(14.4 \%$ vs $28.3 \%)$ compared to endoscopy [90].

\section{CONCLUSIONS}

PD is the most frequently encountered anomaly of the pancreatic ducts. The current evidence demonstrates that it is associated with several conditions like ARP, CP and CAP. The golden standard for diagnosing PD is ERCP but since it is an invasive procedure S-MRCP is a good alternative. In case the patient is symptomatic, endoscopic or surgical treatment should be performed. A high index of suspicion of PD should be present in case of patients with ARP, CP. CAP as well as idiopathic pancreatitis.

Acknowledgements: None.

Pancreas divisum (PD) este cea mai comună variantă de dezvoltare anatomică a ductului pancreatic. Atenția față de PD a crescut semnificativ, deoarece sunt rapoarte că această afecțiune poate provoca pancreatită acută recurentă, pancreatită cronică şi sindrom de durere abdominală cronică. Mai mult, de-a lungul anilor, au existat mai multe rapoarte despre PD asociat cu diferite tipuri de tumori. Există dovezi că PD poate fi asociat cu tumori pancreatice (până la 12,5\% din cazuri). Standardul de aur pentru diagnosticarea $P D$ este cholangiopancreatografia endoscopică retrogradă, dar, din cauză că este o procedură invazivă, rezonanța magnetică în regimul colangiopancreatografia cu secretină este o alternativă mai bună. În cazul în care pacienții sunt simptomatici, trebuie efectuat un tratament endoscopic sau chirurgical. Această revizuire descrie punctele-cheie ale fiziopatologiei, modalitățile de diagnosticare, riscurile de pancreatită şi tumori, precum şi opțiunile de tratament ale PD.

Correspondence to: Serghei Covantev, MD, Junior researcher, Laboratory of Allergology and Clinical Immunology,

"Nicolae Testemitanu" State University of Medicine and Pharmacy, 165, Stefan cel Mare si Sfant Bd. MD-2004,

Chisinau, Republic of Moldova.

E-mail: kovantsev.s.d@gmail.com

\section{REFERENCES}

1. KANNE JP., ROHRMANN CA., JR., LICHTENSTEIN JE. Eponyms in radiology of the digestive tract: historical perspectives and imaging appearances. Part 2. Liver, biliary system, pancreas, peritoneum, and systemic disease. Radiographics : a review publication of the Radiological Society of North America, Inc. 2006; 26(2):465-80.

2. SHARMA M., PATHAK A., RAMESHBABU CS., RAI P., KIRNAKE V., SHOUKAT A. Imaging of pancreas divisum by linear-array endoscopic ultrasonography. Endoscopic Ultrasound. 2016; 5(1):21-9. 
3. QUEST L., LOMBARD M. Pancreas divisum: opinio divisa. Gut. 2000;47(3):317-9.

4. OPIE E. The anatomy of the pancreas. Johns Hopkins Hospital Bull, 1903.

5. JOKIC R., MILOSEVIC P., KONSTANTINIDIS G., VLASKI J., BESERMINJI M. Pancreas divisum: analysis and therapeutic alternatives with a case report. Vojnosanitetski pregled. 2013; 70(6):615-9.

6. WHITE JJ., ROBERTS ZN., GEST TR., BEALE EG. Pancreas divisum: a common developmental variant that deserves attention in preclinical medical education. Clinical anatomy (New York, NY). 2014; 27(7):1038-45.

7. ISHII H., ARAI K., FUKUSHIMA M., MARUOKA Y., HOSHINO M., NAKAMURA A., et al. Fusion variations of pancreatic ducts in patients with anomalous arrangement of pancreaticobiliary ductal system. Journal of hepato-biliarypancreatic surgery. 1998; 5(3):327-32.

8. AYARI H., REBII S., AYARI M., HASNI R., ZOGHLAMI A. L'ansa pancreatica: une cause rare de pancréatite aigue. The Pan African Medical Journal. 2012; 13:33.

9. GONOI W., AKAI H., HAGIWARA K., AKAHANE M., HAYASHI N., MAEDA E., et al. Meandering main pancreatic duct as a relevant factor to the onset of idiopathic recurrent acute pancreatitis. PloS one. 2012; 7(5):e37652.

10. HAYASHI TY., GONOI W., YOSHIKAWA T., HAYASHI N., OHTOMO K. Ansa pancreatica as a predisposing factor for recurrent acute pancreatitis. World journal of gastroenterology. 2016; 22(40):8940-8.

11. KOZAREK RA., BALL TJ., PATTERSON DJ., BRANDABUR JJ., RALTZ SL. Endoscopic approach to pancreas divisum. Digestive diseases and sciences. 1995; 40(9):1974-81.

12. TAKUMA K., KAMISAWA T., HARA S., TABATA T., KURUMA S., CHIBA K., et al. Etiology of recurrent acute pancreatitis, with special emphasis on pancreaticobiliary malformation. Advances in medical sciences. 2012; 57(2):244-50.

13. CHALAZONITIS NA., LACHANIS BS., LASPAS F., PTOHIS N., TSIMITSELIS G., TZOVARA J. Pancreas divisum: magnetic resonance cholangiopancreatography findings. Singapore medical journal. 2008; 49(11):951-4; quiz 5.

14. KOZU T., SUDA K., TOKI F. Pancreatic development and anatomical variation. Gastrointestinal endoscopy clinics of North America. 1995; 5(1):1-30.

15. LEHMAN GA., SHERMAN S. Diagnosis and therapy of pancreas divisum. Gastrointestinal endoscopy clinics of North America. 1998; 8(1):55-77.

16. STARITZ M., MEYER ZUM BUSCHENFELDE KH. Elevated pressure in the dorsal part of pancreas divisum: the cause of chronic pancreatitis? Pancreas. 1988; 3(1):108-10.

17. WARSHAW AL., RICHTER JM., SCHAPIRO RH. The cause and treatment of pancreatitis associated with pancreas divisum. Annals of surgery. 1983; 198(4):443-52.

18. WARSHAW AL., SIMEONE JF., SCHAPIRO RH., FLAVIN-WARSHAW B. Evaluation and treatment of the dominant dorsal duct syndrome (pancreas divisum redefined). American journal of surgery. 1990; 159(1):59-64; discussion-6.

19. HE H., LU WF., KE YZ., ZHANG YM. An experimental study in etiologic effect of pancreas divisum on chronic pancreatitis and its pathogenesis. World journal of gastroenterology. 1998;4(6):533-5.

20. SPICAK J., POULOVA P., PLUCNAROVA J., REHOR M., FILIPOVA H., HUCL T. Pancreas divisum does not modify the natural course of chronic pancreatitis. Journal of gastroenterology. 2007; 42(2):135-9.

21. BARTHET M., VALANTIN V., SPINOSA S., BERNARD JP., SAHEL J. Clinical course and morphological features of chronic calcifying pancreatitis associated with pancreas divisum. European journal of gastroenterology \& hepatology. 1995; 7(10):993-8.

22. BRET PM., REINHOLD C., TAOUREL P., GUIBAUD L., ATRI M., BARKUN AN. Pancreas divisum: evaluation with MR cholangiopancreatography. Radiology. 1996; 199(1):99-103.

23. BONINSEGNA E., MANFREDI R., VENTRIGLIA A., NEGRELLI R., PEDRINOLLA B., MEHRABI S., et al. Santorinicele: secretin-enhanced magnetic resonance cholangiopancreatography findings before and after minor papilla sphincterotomy. European radiology. 2015; 25(8):2437-44.

24. MANFREDI R., COSTAMAGNA G., BRIZI MG., SPINA S., MARESCA G., VECCHIOLI A, et al. Pancreas divisum and "santorinicele": diagnosis with dynamic MR cholangiopancreatography with secretin stimulation. Radiology. $2000 ; 217$ (2):403-8.

25. DE FILIPPO M., CALABRESE M., QUINTO S., RASTElli A., BERTELlini A., MARTORA R., et al. Congenital anomalies and variations of the bile and pancreatic ducts: magnetic resonance cholangiopancreatography findings, epidemiology and clinical significance. La Radiologia medica. 2008; 113(6):841-59.

26. MOSLER P., AKISIK F., SANDRASEGARAN K., FOGEL E., WATKINS J., ALAZMI W., et al. Accuracy of magnetic resonance cholangiopancreatography in the diagnosis of pancreas divisum. Digestive diseases and sciences. 2012; 57(1):170-4.

27. STIMEC B., BULAJIC M., KORNETI V., MILOSAVLJEVIC T., KRSTIC R., UGLJESIC M. Ductal morphometry of ventral pancreas in pancreas divisum. Comparison between clinical and anatomical results. The Italian journal of gastroenterology. 1996; 28(2):76-80.

28. TAJ MA., QURESHI S., GHAZANFAR S., SIDDIQUI AR., NIAZ SK., QURAISHY MS., et al. Pancreas Divisum. Journal of the College of Physicians and Surgeons--Pakistan: JCPSP. 2016; 26(2):96-9.

29. LAI R., FREEMAN ML., CASS OW., MALLERY S. Accurate diagnosis of pancreas divisum by linear-array endoscopic ultrasonography. Endoscopy. 2004; 36(8):705-9.

30. SMANIO T. Proposed nomenclature and classification of the human pancreatic ducts and duodenal papillae. Study based on 200 post mortems. International surgery. 1969; 52(2):125-41.

31. LIAO Z., GAO R., WANG W., YE Z., LAI XW., WANG XT., et al. A systematic review on endoscopic detection rate, endotherapy, and surgery for pancreas divisum. Endoscopy. 2009; 41(5):439-44.

32. MCCUNE WS., SHORB PE., MOSCOVITZ H. Endoscopic cannulation of the ampulla of vater: a preliminary report. Annals of surgery. 1968; 167(5):752-6. 
33. CARNES ML., ROMAGNUOLO J., COTTON PB. Miss rate of pancreas divisum by magnetic resonance cholangiopancreatography in clinical practice. Pancreas. 2008; 37(2):151-3.

34. SANDRASEGARAN K., COTE GA., TAHIR B., AHMAD I., TANN M., AKISIK FM., et al. The utility of secretin-enhanced $M R C P$ in diagnosing congenital anomalies. Abdominal imaging. 2014; 39(5):979-87.

35. BULOW R., SIMON P., THIEL R., THAMM P., MESSNER P., LERCH MM., et al. Anatomic variants of the pancreatic duct and their clinical relevance: an MR-guided study in the general population. European radiology. 2014; 24(12):3142-9.

36. ADLER DG., BARON TH., DAVILA RE., EGAN J., HIROTA WK., LEIGHTON JA., et al. ASGE guideline: the role of ERCP in diseases of the biliary tract and the pancreas. Gastrointestinal endoscopy. 2005; 62(1):1-8.

37. KUSHNIR VM., WANI SB., FOWLER K., MENIAS C., VARMA R., NARRA V., et al. Sensitivity of endoscopic ultrasound, multidetector computed tomography, and magnetic resonance cholangiopancreatography in the diagnosis of pancreas divisum: a tertiary center experience. Pancreas. 2013; 42(3):436-41.

38. ASAYAMA Y., FANG W., STOLPEN A., KUEHN D. Detectability of pancreas divisum in patients with acute pancreatitis on multi-detector row computed tomography. Emergency radiology. 2012; 19(2):121-5.

39. RANA SS., BHASIN DK., SHARMA V., RAO C., SINGH K.. Role of endoscopic ultrasound in the diagnosis of pancreas divisum. Endosc Ultrasound. 2013; 2(1):7-10.

40. FREEMAN ML., DISARIO JA., NELSON DB., FENNERTY MB., LEE JG., BJORKMAN DJ., et al. Risk factors for postERCP pancreatitis: a prospective, multicenter study. Gastrointestinal endoscopy. 2001; 54(4):425-34.

41. COTTON PB., LEHMAN G., VENNES J., GEENEN JE., RUSSELL RC., MEYERS WC., et al. Endoscopic sphincterotomy complications and their management: an attempt at consensus. Gastrointestinal endoscopy. 1991; 37(3):383-93.

42. ANDRIULLI A., LOPERFIDO S., NAPOLITANO G., NIRO G., VALVANO MR., SPIRITO F., et al. Incidence rates of postERCP complications: a systematic survey of prospective studies. The American journal of gastroenterology. 2007; 102(8):1781-8.

43. SALMINEN P., LAINE S., GULLICHSEN R. Severe and fatal complications after ERCP: analysis of 2555 procedures in a single experienced center. Surgical endoscopy. 2008; 22(9):1965-70.

44. VEGTING IL., TABBERS MM., TAMINIAU JA., ARONSON DC., BENNINGA MA., RAUWS EA. Is endoscopic retrograde cholangiopancreatography valuable and safe in children of all ages? Journal of pediatric gastroenterology and nutrition. 2009; 48(1):66-71.

45. ROSEN JD., LANE RS., MARTINEZ JM., PEREZ EA., TASHIRO J., WAGENAAR AE., et al. Success and safety of endoscopic retrograde cholangiopancreatography in children. Journal of pediatric surgery. 2017; 52(7):1148-51.

46. LU Y., XU B., CHEN L., BIE LK., GONG B. Endoscopic Intervention through Endoscopic Retrograde Cholangiopancreatography in the Management of Symptomatic Pancreas Divisum: A Long-Term Follow-Up Study. Gut and liver. 2016; 10(3):476-82.

47. MOFFATT DC., COTE GA., AVULA H., WATKINS JL., MCHENRY L., SHERMAN S., et al. Risk factors for ERCP-related complications in patients with pancreas divisum: a retrospective study. Gastrointestinal endoscopy. 2011; 73(5):963-70.

48. SICA GT., BRAVER J., COONEY MJ., MILLER FH., CHAI JL., ADAMS DF. Comparison of endoscopic retrograde cholangiopancreatography with MR cholangiopancreatography in patients with pancreatitis. Radiology. 1999; 210(3):605-10.

49. KAMISAWA T., TU Y., EGAWA N., TSURUTA K., OKAMOTO A., KAMATA N. MRCP of congenital pancreaticobiliary malformation. Abdominal imaging. 2007; 32(1):129-33.

50. CZAKÓ L., TAKÁCS T., MORVAY Z., CSERNAY L., LONOVICS J. Diagnostic role of secretin-enhanced MRCP in patients with unsuccessful ERCP. World Journal of Gastroenterology : WJG. 2004; 10(20):3034-8.

51. BORASCHI P., DONATI F., CERVELLI R., PACCIARDI F. Secretin-stimulated MR cholangiopancreatography: spectrum of findings in pancreatic diseases. Insights into Imaging. 2016; 7(6):819-29.

52. SHEN Z., MUNKER S., ZHOU B., LI L., YU C, LI Y. The Accuracies of Diagnosing Pancreas Divisum by Magnetic Resonance Cholangiopancreatography and Endoscopic Ultrasound: A Systematic Review and Meta-analysis. Scientific reports. 2016; 6:35389.

53. PAPANIKOLAOU IS., KARATZAS PS., TRIANTAFYLLOU K., ADLER A. Role of pancreatic endoscopic ultrasonography in 2010. World Journal of Gastrointestinal Endoscopy. 2010; 2(10):335-43.

54. Gregg JA. Pancreas divisum: its association with pancreatitis. American journal of surgery. 1977; 134(5):539-43.

55. ROSCH W., KOCH H., SCHAFFNER O., DEMLING L. The clinical significance of the pancreas divisum. Gastrointestinal endoscopy. 1976; 22(4):206-7.

56. COTTON PB. Congenital anomaly of pancreas divisum as cause of obstructive pain and pancreatitis. Gut. 1980; 21(2):105-14.

57. Coyle WJ., Pineau BC., Tarnasky PR., Knapple WL., Aabakken L., Hoffman BJ., et al. Evaluation of unexplained acute and acute recurrent pancreatitis using endoscopic retrograde cholangiopancreatography, sphincter of Oddi manometry and endoscopic ultrasound. Endoscopy. 2002; 34(8):617-23.

58. FISCHER M., HASSAN A., SIPE BW., FOGEL EL., MCHENRY L., SHERMAN S., et al. Endoscopic retrograde cholangiopancreatography and manometry findings in 1,241 idiopathic pancreatitis patients. Pancreatology: official journal of the International Association of Pancreatology (IAP) [et al.]. 2010; 10(4):444-52.

59. GUPTA A., RAI P., SINGH V., GUPTA RK., SARASWAT VA. Intrahepatic biliary duct branching patterns, cystic duct anomalies, and pancreas divisum in a tertiary referral center: A magnetic resonance cholangiopancreaticographic study. Indian journal of gastroenterology : official journal of the Indian Society of Gastroenterology. 2016; 35(5):379-84.

60. WANG DB., YU J., FULCHER AS., TURNER MA. Pancreatitis in patients with pancreas divisum: imaging features at MRI and MRCP. World journal of gastroenterology. 2013; 19(30):4907-16.

61. KAMISAWA T., TU Y., EGAWA N., TSURUTA K., OKAMOTO A. Clinical implications of incomplete pancreas divisum. JOP : Journal of the pancreas. 2006; 7(6):625-30. 
62. TAKUMA K., KAMISAWA T., TABATA T., EGAWA N., IGARASHI Y. Pancreatic diseases associated with pancreas divisum. Digestive surgery. 2010; 27(2):144-8.

63. ADIBELLI ZH., ADATEPE M., IMAMOGLU C., ESEN OS., ERKAN N., YILDIRIM M. Anatomic variations of the pancreatic duct and their relevance with the Cambridge classification system: MRCP findings of 1158 consecutive patients. Radiology and oncology. 2016; 50(4):370-7.

64. BALLARD DD., FLUECKIGER JR., FOGEL EL., MCHENRY L., LEHMAN GA., WATKINS JL., et al. Evaluating adults with idiopathic pancreatitis for genetic predisposition: higher prevalence of abnormal results with use of complete gene sequencing. Pancreas. 2015; 44(1):116-21.

65. BERTIN C., PELLETIER AL., VULLIERME MP., BIENVENU T., REBOURS V., HENTIC O., et al. Pancreas divisum is not a cause of pancreatitis by itself but acts as a partner of genetic mutations. The American journal of gastroenterology. 2012; 107(2):311-7.

66. GARG PK., KHAJURIA R., KABRA M., SHASTRI SS. Association of SPINK1 gene mutation and CFTR gene polymorphisms in patients with pancreas divisum presenting with idiopathic pancreatitis. Journal of clinical gastroenterology. 2009; 43(9):848-52.

67. MASAMUNE A., KUME K., SHIMOSEGAWA T. Differential roles of the SPINK1 gene mutations in alcoholic and nonalcoholic chronic pancreatitis. Journal of gastroenterology. 2007; 42 Suppl 17:135-40.

68. TRUNINGER K., WITT H., KOCK J., KAGE A., SEIFERT B., AMMANN RW., et al. Mutations of the serine protease inhibitor, Kazal type 1 gene, in patients with idiopathic chronic pancreatitis. The American journal of gastroenterology. 2002; 97(5):1133-7.

69. MORISE Z., YAMAFUJI K., TSUJI T., ASAMI A., TAKESHIMA K., HAYASHI N., et al. A giant retention cyst of the pancreas (cystic dilatation of dorsal pancreatic duct) associated with pancreas divisum. Journal of gastroenterology. 2002; 37(12):1079-82.

70. PETERSON MS., SLIVKA A. Santorinicele in pancreas divisum: diagnosis with secretin-stimulated magnetic resonance pancreatography. Abdominal imaging. 2001; 26(3):260-3.

71. BROWDER W., GRAVOIS E., VEGA P., ERTAN A. Obstructing pseudocyst of the duct of Santorini in pancreas divisum. The American journal of gastroenterology. 1987; 82(3):258-61

72. SISMAN G. Concomitant pancreas divisum and double pylorus: a case report. JOP : Journal of the pancreas. $2014 ; \mathbf{1 5}(6): 632$.

73. MORIO R., IMAMURA M., FUKUHARA T., KAN H., FUJINO H., KAWAOKA T., et al. [A case of chronic hepatitis $C$ with pancreas divisum and acute pancreatitis during combination treatment with telaprevir/peginterferon/ribavirin]. Nihon Shokakibyo Gakkai zasshi = The Japanese journal of gastro-enterology. 2014; 111(10):1997-2003.

74. WATANABE D., MIURA K., GOTO T., NANJO H., YAMAMOTO Y., OHNISHI H. Solid pseudopapillary tumor of the pancreas with concomitant pancreas divisum. A case report. JOP : Journal of the pancreas. 2010; 11(1):45-8.

75. MASATSUGU T., YAMAGUCHI K., CHIJIIWA K., NISHIYAMA K., TANAKA M. Serous cystadenoma of the pancreas associated with pancreas divisum. Journal of gastroenterology. 2002; 37(8):669-73.

76. JARA LETELIER DI., BONOTTO ML., ARDENGH JC. Somatostatinoma of the minor duodenal papilla associated with pancreas divisum treated by endoscopic papillectomy. Endoscopy. 2016; 48 Suppl 1:E135-7.

77. WAISBERG J., DE MATOS LL., WAISBERG DR., DOS SANTOS HV., FERNEZLIAN SM., CAPELOZZI VL. Carcinoid of the minor duodenal papilla associated with pancreas divisum: Case report and review of the literature. Clinics (Sao Paulo, Brazil). 2006; 61(4):365-8.

78. KAMISAWA T., YOSHIIKE M., EGAWA N., TSURUTA K., OKAMOTO A., FUNATA N. Pancreatic tumor associated with pancreas divisum. Journal of gastroenterology and hepatology. 2005; 20(6):915-8.

79. NISHINO T., TOKI F., OI I., OYAMA H., HATORI T., SHIRATORI K. Prevalence of pancreatic and biliary tract tumors in pancreas divisum. Journal of gastroenterology. 2006; 41(11):1088-93.

80. KAMISAWA T., TU Y., EGAWA N., TSURUTA K., OKAMOTO A., MATSUKAWA M. Pancreas divisum in pancreaticobiliary maljunction. Hepato-gastroenterology. 2008; 55(81):249-53.

81. ADIBELLI ZH., ADATEPE M., ISAYEVA L., ESEN OS., YILDIRIM M. Pancreas divisum: A risk factor for pancreaticobiliary tumors - an analysis of 1628 MR cholangiography examinations. Diagnostic and interventional imaging. 2017; 98(2):141-7.

82. OBANA T., FUJITA N., NODA Y., KOBAYASHI G., ITO K., HORAGUCHI J, et al. Small pancreatic cancer with pancreas divisum preoperatively diagnosed by pancreatic juice cytology. Internal medicine (Tokyo, Japan). 2009; 48(18):1661-6.

83. MICHAILIDIS L., ASLAM B., GRIGORIAN A., MARDINI H. The efficacy of endoscopic therapy for pancreas divisum: a meta-analysis. Annals of gastroenterology. 2017; 30(5):550-8.

84. WILCOX CM., SEAY T., KIM H., VARADARAJULU S. Prospective Endoscopic Ultrasound-Based Approach to the Evaluation of Idiopathic Pancreatitis: Causes, Response to Therapy, and Long-term Outcome. Am J Gastroenterol. 2016; 111(9):1339-48.

85. VITALE GC., VITALE M., VITALE DS., BINFORD JC., HILL B. Long-term follow-up of endoscopic stenting in patients with chronic pancreatitis secondary to pancreas divisum. Surgical endoscopy. 2007; 21(12):2199-202.

86. Neblett WW., 3rd, O'Neill JA, Jr. Surgical management of recurrent pancreatitis in children with pancreas divisum. Annals of surgery. 2000; 231(6):899-908.

87. SNAJDAUF J., PETRU O., NAHLOVSKY J., RYGL M., FRYBOVA B., BRONSKY J., et al. Pancreas Divisum in Children and Duodenum-Preserving Resection of the Pancreatic Head. Eur J Pediatr Surg. 2018; 28(3):250-254.

88. SCHLOSSER W., RAU BM., POCH B., BEGER HG. Surgical treatment of pancreas divisum causing chronic pancreatitis: the outcome benefits of duodenum-preserving pancreatic head resection. Journal of gastrointestinal surgery : official journal of the Society for Surgery of the Alimentary Tract. 2005; 9(5):710-5. 
89. IZZO P., DI CELLO P., PUGLIESE F., IZZO S., GRANDE R., BIANCUCCI F., et al. Pancreas divisum: correlation between anatomical abnormalities and bile precipitation in the gallbladder in seven patients. Il Giornale di chirurgia. 2016; 37(4):155-7.

90. HAFEZI M., MAYSCHAK B., PROBST P., BUCHLER MW., HACKERT T., MEHRABI A. A systematic review and quantitative analysis of different therapies for pancreas divisum. American journal of surgery. 2017, 214(3):525-537.

Received May 29, 2018 